\title{
Penerapan Algoritma Apostolico Dalam Pencarian Tiket Pemesanan dan Pendaftaran Seminar
}

\author{
Dias Syahril Nurrachman \\ Fakultas Teknologi Komunikasi dan Informatika, Teknik Informatika, Universitas Nasional, Jakarta, Indonesia \\ Email: dias.syahriln1997@gmail.com
}

\begin{abstract}
Abstrak-Pada acara sebuah seminar, dalam penjualan tiket seminar dilakukan secara manual, yaitu dengan proses pendaftaran peserta seminar. Dimana pada kegiatan tersebut peserta harus mengisi data secara manual yang diperlukan untuk pembuatan sertifikat pada akhir kegiatan. Meninjau mengenai hal tersebut, teknologi internet dapat dimanfaatkan untuk pendaftaran seminar secara online, sehingga mempermudah penyelenggara seminar untuk mengetahui akumulasi hasil acara seminar. Pada penelitian ini akan dikembangkan sebuah sistem untuk penjualan tiket seminar berbasis website sebagai sistem afiliasi penjualan tiket seminar, yaitu dengan membantu penyelenggara seminar untuk mempromosikan atau memasarkan penjualan tiket seminar. Dengan memanfaatkan aplikasi ini, informasi menjadi lebih mudah disampaikan dan didapatkan, baik penyelenggara seminar maupun peserta seminar. Sehingga memberikan performa kegiatan yg lebih baik. Sistem yang dibangun menggunakan framework codeigniter berbasis PHP yang open source dan menggunakan algoritma apostolico diterapkan untuk proses pencarian kategori seminar pada penyimpanan database dengan menghasilkan daftar seleksi dari kategori seminar berdasarkan pada kata kunci yang diinputkan.
\end{abstract}

Kata Kunci: Pendaftaran Seminar; Seminar Nasional; Algoritma Apostolico; Tiket Seminar; Pemesanan Seminar

\begin{abstract}
At the seminar, the sale of seminar tickets is done manually, that is, by registering seminar participants. Where in this activity the participants have to manually fill in the data needed to create a certificate at the end of the activity. Accordingly, internet technology can be used for online seminar registration, making it easier for seminar organizers to know the results of the accumulated seminars. In this study, a website-based seminar ticket sales system will be developed as a seminar ticket sales affiliate system, namely by helping seminar organizers to promote or market seminar ticket sales. By using this application, information becomes easier to convey and obtain, both seminar organizers and seminar participants. To provide better activity performance. The system is built using an open source PHP codeigniter framework and uses the apostolico algorithm applied to the seminar category search process on database storage by generating a list of seminar category options based on the keywords entered.
\end{abstract}

Keywords: Seminar Registration; National Seminar; Apostolico Algorithm; Seminar Tickets; Seminar Booking

\section{PENDAHULUAN}

Saat ini, semakin banyak mahasiswa yang ingin mengikuti seminar khususnya di Universitas Nasional, ada sebagian mahasiswa yang datang dan mengantre panjang untuk mendapatkan kuota dalam suatu seminar. Proses ini sangat melelahkan, karena banyaknya jumlah peminat yang ingin mengikuti seminar. Maka biasanya membutuhkan waktu lama untuk mengantre, mengisi data diri, melakukan pembayaran, dan yang paling mengecewakan adalah saat sudah lama mengantre ternyata kuotanya sudah habis.

Para Mahasiswa di Universitas Nasional sangat membutuhkan suatu sistem pemesanan seminar berbasis online. Sistem pendaftaran seminar secara online ini menyediakan informasi seminar dan juga bisa langsung pemesanan tiket secara online untuk mengikuti seminar tanpa harus kehilangan banyak waktu. Peserta seminar biasanya membeli tiket secara manual dari panitia atau langsung ke tempat yang menyelenggarakan.

Oleh karena itu, dibuat sebuah sistem pemesanan berbasis website untuk melakukan pemesanan tiket seminar secara online, agar peserta seminar bisa melakukan pemesanan dimana saja sehingga mendapatkan tiket dengan mudah. Dari pengamatan yang dilakukan dapat disimpulkan antara lain dengan tidak adanya aplikasi pemesanan seminar akan memakan waktu yang lama dalam proses pemesanan seminar. Karena itu, dibuat sebuah rancangan Aplikasi pemesanan tiket seminar berbasis website yang dapat membantu peserta seminar, maupun penyelenggara seminar [1], Pembuatan website pada penelitian sebelumnya mengaplikasikan kemudahan pendaftaran melalui sebuah form, kemudian mengolah datanya secara cepat, tepat dan akurat untuk mengurangi kesalahan pencatatan dan pelaporan data peserta [1], [2]

Penelitian terdahulu yang penerapan algoritma Apostolico, menghasilkan pencarian yang sesuai dengan yang diharapkan [3], Penelitian terkait hal berikut juga dilakukan, dimana aplikasi dapat memperoleh hasil pencarian berupa cord biola secara efektif dan efisien dengan menggunakan algoritma string matching, yaitu algoritma Apostolico [4], Algoritma Apostolico merupakan salah satu jenis algoritma string matching yang melakukan perbandingan karakter pada teks sebanyak 3n/2 dimulai dari kiri ke kanan pada kasus terburuknya. Algoritma Apostolico terdiri dari dua fase, yaitu preprocessing dan fase pencarian string [5].

Pada penelitian ini penulis bertujuan untuk memanfaatkan penggunaan teknologi dalam melakukan pendaftaran seminar yang diharapkan dapat digunakan sebagai alat bantu yang mempermudah dalam verifikasi proses pendaftaran seminar. 


\section{METODOLOGI PENELITIAN}

\subsection{Tahapan Penelitian}

Metodologi dalam penelitian yang digunakan dalam pembuatan sistem pendaftaran dan pemesanan seminar dengan tiket berbasis website meliputi:

1. Analisis Kebutuhan Sistem

Proses ini terdiri dari pengumpulan data dalam pembangunan sistem ini dengan cara observasi dan melakukan wawancara kepada organisasi/instansi yang merencanakan acara seminar maupun seseorang yang mengikuti sebuah acara seminar.

a. Analisis Kebutuhan Hardware (Perangkat Keras)

Perangkat keras yang digunakan yaitu laptop, untuk mengoperasikan sistem pendaftaran seminar.

b. Analisis Kebutuhan Software (Perangkat Lunak)

Perangkat Lunak yang digunakan yaitu CPanel sebagai server localhost dimana sistem dan database di simpan, browser digunkan ntuk menampilakan halaman sistem dan SublimeText digunakan untuk penulisan coding untuk sistem yang akan dibuat

2. Perancangan Sistem

Pada tahap ini membuat desain pada rancangan antar muka user saat mendaftarkan seminar, pemesanan seminar, dan pembayaran seminar pada aplikasi. Pada tahap ini juga akan dijelaskan tentang cara kerja sistem, dan membuat desain User Interface. Untuk user diberikan hak akses login, melihat informasi seminar, melakukkan pemesanan tiket seminar, melakukan pembayaran seminar, menu untuk mencetak tiket, dan menu logout.

3. Pengujian Aplikasi

Pada tahap ini pengujian bertujuan untuk mengetahui apakah fitur yang terdapat pada sistem ini dapaat berjalan sesuai dengan rencana.

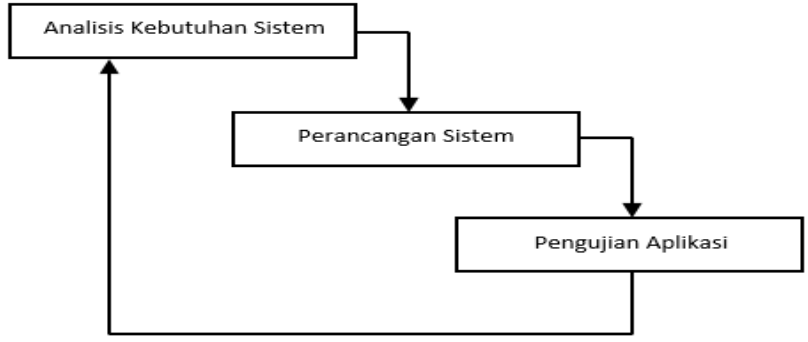

Gambar 1. Tahapan Penelitian

\subsection{Algoritma Apostolico}

Algoritma Apostolico merupakan salah satu algoritma pencarian string dalam banyak jenis algoritma pencarian string. Algoritma sederhana yang melakukan perbandingan karakter dalam teks. Algoritma ini terdiri dari dua fase, fase pre-processing dan fase pencarian string. Pada fase pre-processing diberlakukan fungsi untuk menentukan jumlah penggeseran pattern terbesar dengan digunakan perbandingan pencarian string. Kemudian pada fase pencarian string diberlakukan perbandingan pattern pada teks [6].

\section{HASIL DAN PEMBAHASAN}

\subsection{Penerapan Algoritma Apostolico}

Bersumber pada analisis pada implementasi algoritma apostolico dengan permasalahan pencarian jenis seminar, penulis membuat rancangan proses kerja sistem dengan bantuan dalam merancang aplikasi pencarian kategori seminar dengan algoritma apostolico [8].

Pada penggunaan algoritma apostolico dalam perancangan pencarian kategori seminar, pada kasusnya adalah cara menyeleksi seminar dalam data penyimpanan informasi agar menciptakan suatu catatan daftar seminar menurut kata kunci pencarian. Algoritma ini bekerja dengan manyamakan tiap index karakter dengan kata kunci string yang di seleksi. Pencarian kata kunci dalam algoritma apostolico diawali dalam mengaplikasikan preprocessing dengan kata kunci. pre-processing dilakukan untuk dilihat dalam index keberapa dari string yang diseleksi kesamaannya pada karakter kata kunci [6].

Penggunaan algoritma apostolico menggambarkan tahap yang dibuat untuk menyelesaikan permasalahan pada pencarian kategori seminar pada website ini. Pencarian pada string "Seminar FTKI dan Seminar FISIP" dengan kata kunci "FTKI". Langkah awal pada pre-processing adalah dengan menyusun pada setiap karakter string yang di seleksi tanpa adanya pengulangan karakter. Pada string "Seminar FTKI dan Seminar FISIP" yang diterapkan, hasil penyusunan pada karakter string adalah "adfikmnprst". Selanjutnya, penyeleksian kesamaan pada 
ISSN 2614-5278 (media cetak), ISSN 2548-8368 (media online)

Available Online at https://ejurnal.stmik-budidarma.ac.id/index.php/mib DOI 10.30865/mib.v5i1.2642

setiap karakter string dari kata kunci, diawali pada karakter index yang paling kanan. Dari pencocokan string "adfikmnprst", dapat dilihat karakter "a" dari string diseleksi tidak sama dengan kata kunci.

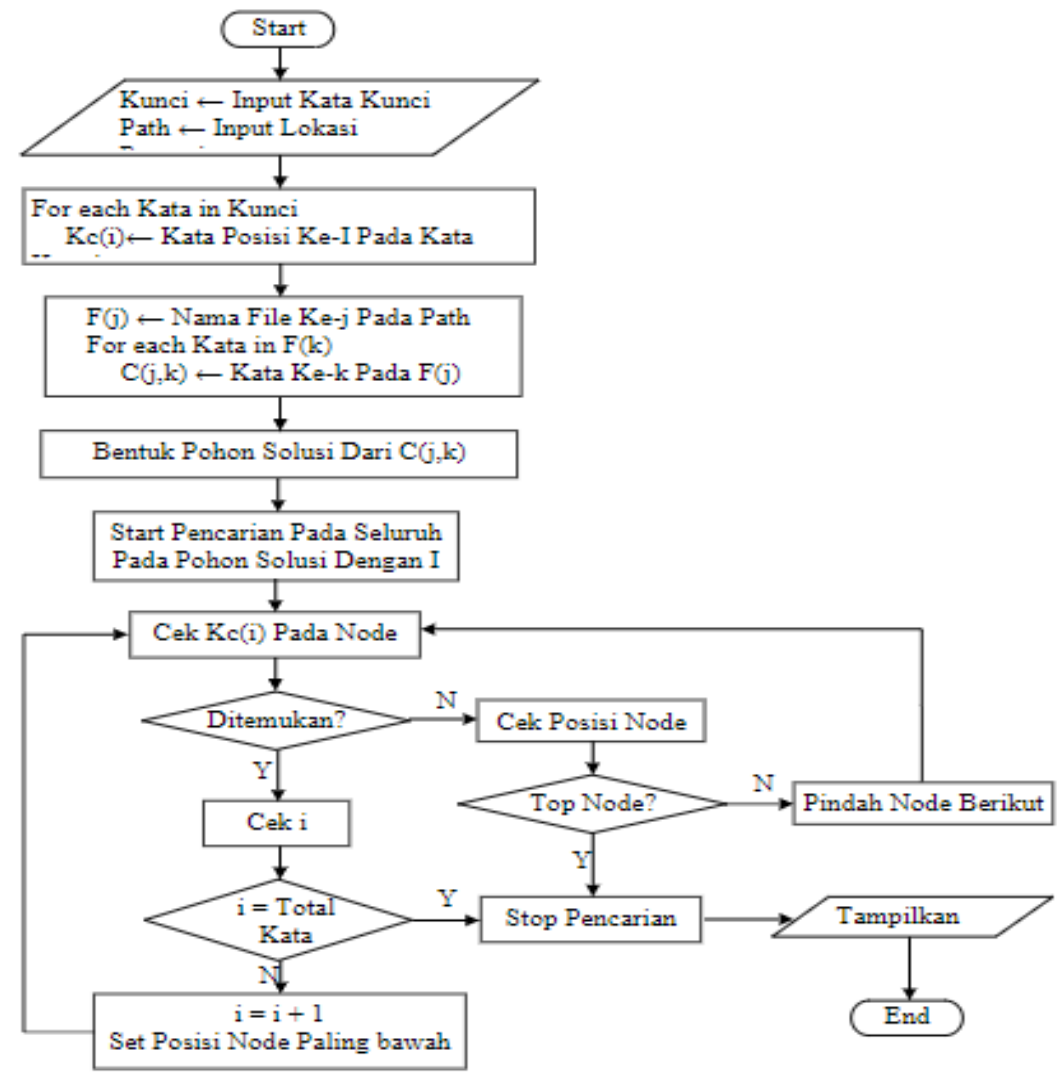

Gambar 2. Proses pencarian kategori seminar pada aplikasi

Pada karakter yang tidak cocok disebut karakter buruk, lalu diberi pengkodean $n+1$, sehingga $n$ yaitu nilai maksimal yang terdapat pada index. Dikarenakan panjang pada "Ftki" berjumlah 4 (empat) karakter, index yang didapat dengan kata kunci yaitu 0 sampai 3. Dalam jumlah maksimal pada kata kunci index sebesar 3 (tiga), maka pengkodean di terapkan pada karakter buruk di contoh kasus ini 4 (empat). Pada karakter yang kedua dalam string, yaitu karakter "d", dapat dilihat pada karakter ini tidak didapatkan dalam kata kunci, oleh karena itu diberikan kembali pengkodean nilai sebesar 4 (empat). Selanjutnya adalah karakter "f", karakter ini ditemukan dalam kata kunci, terdapat pada index ke 1 (satu). Seterusnya dilakukan penyeleksian pada tiap karakter string yang diseleksi, sampai di peroleh hasil yang dapat dilihat pada tabel 1 [7].

Tabel 1. Hasil Pre-Processing

\begin{tabular}{|c|c|}
\hline Character & 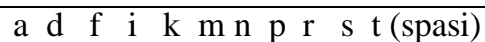 \\
\hline Code & $\begin{array}{lllllllllll}6 & 6 & 6 & 6 & 6 & 5 & 4 & 5 & 3 & 4 & 6\end{array}$ \\
\hline
\end{tabular}

Setelah pre-processing, berikutnya proses menyamakan karakter dalam kata kunci dengan string. Proses menyamakan diawali pada karakter pertama dalam string yang diseleksi. Dikarenakan panjang kata kunci pada kasus ini 4 (empat) karakter, maka dilakukan penyesuain pertama dengan menyamakan karakter string "seminar" dengan kata kunci. Sebagaimana dapat dilihat pada tabel 2, karakter paling akhir pada kata kunci, yaitu "i" tidak memiliki kecocokan dalam karakter paling akhir dalam string, yaitu "t" [7].

Tabel 2. Pencocokan I

\begin{tabular}{llll}
\hline String & n (spasi) & f t \\
\hline Kata Kunci & f & t & k i \\
Cocok & & & X \\
\hline
\end{tabular}

Dikarenakan tidak didapatkan kecocokan, maka dilakukan shift. Proses shift digunakan dengan langkah awal dilihat karakter yang di bandingkan dalam karakter buruk atau bukan. Dalam kasus ini, karakter "a" adalah karakter buruk dengan nilai pengkodean 4 (empat) sehingga proses shift yang digunakan adalah bad-character shift. bad-character shift yaitu digeserkan karakter sebanyak nilai kode pada karakter yang dibandingkan. Selanjutnya shift yang digunakan dengan menggeserkan posisi index pencarian string sebanyak 4 (empat) karakter ke kanan [7]. 
JURNAL MEDIA INFORMATIKA BUDIDARMA

Volume 5, Nomor 1, Januari 2021, Page 216-223

ISSN 2614-5278 (media cetak), ISSN 2548-8368 (media online)

Available Online at https://ejurnal.stmik-budidarma.ac.id/index.php/mib

DOI 10.30865/mib.v5i1.2642

Tabel 3. Pencocokkan III

\begin{tabular}{llll}
\hline String & r (spasi) f t k i \\
\hline $\begin{array}{l}\text { Kata Kunci } \\
\text { Cocok }\end{array}$ & f t & k i & \\
\hline
\end{tabular}

Selanjutnya, diterapkan persamaan karakter string " ftk". Sebagaimana terlihat pada Tabel 4, karakter yang terdapat pada bagian paling akhir kata kunci, yaitu "i" memiliki kesamaan pada karakter paling akhir dalam string, yaitu "i" [7].

Tabel 4. Pencocokkan IV

\begin{tabular}{llll}
\hline String & f & t & k i \\
\hline Kata Kunci & f & t & k i \\
Cocok & V & V & V V \\
\hline
\end{tabular}

Pada langkah ini, proses diberhentikan, karena sudah ditemukan kata yang sama pada string "Seminar FTKI dan Seminar FISIP" dengan menggunakan kata kunci "Ftki". Proses diberhentikan setelah melalui 3 (tiga) kali pencocokan, dengan 7 (tujuh) karakter yang dibandingkan [7].

\subsection{Use Case Diagram}

Pada diagram use case ini, user terbagi menjadi 7 akses, yaitu akses login/Registrasi, akses melihat daftar seminar, akses pesan tiket seminar, akses melihat daftar pesanan, akses melihat halaman pembayaran, akses mencetak tiket seminar, dan akses untuk logout . Gambaran dari sistem pemesanan dan pendaftaran tiket seminar dapat dilihat pada use case berikut ini.

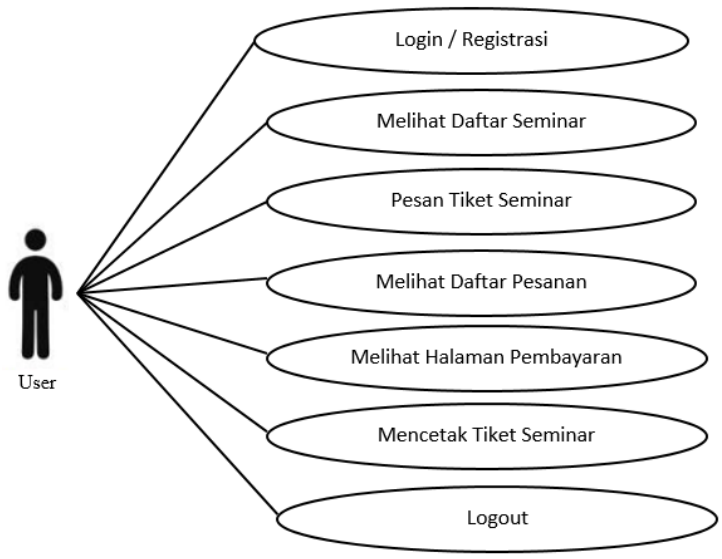

Gambar 3. Use Case Sistem Pemesanan Seminar Online

\subsection{Implementasi Program}

\section{Halaman Home/Landing Page}

Fitur ini berada di halaman paling awal website., fitur home sama dengan fitur home page, yang berisikan tujuan $\&$ informasi website. Tampilan dapat dilihat pada Gambar 4.

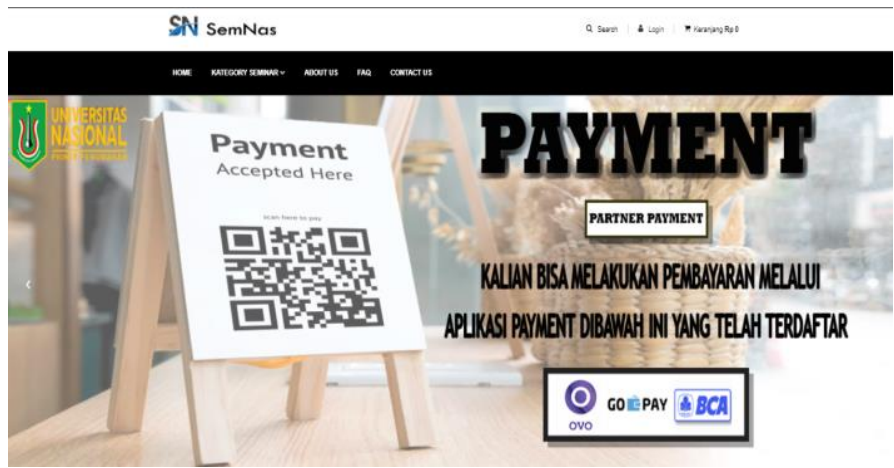

Gambar 4. Tampilan Home

\section{Halaman Daftar Seminar}

Pada Halaman Daftar seminar, user memilih daftar seminar yang tersedia dan melakukkan pemesanan tiket seminar. Tampilan dapat dilihat pada Gambar 5. 


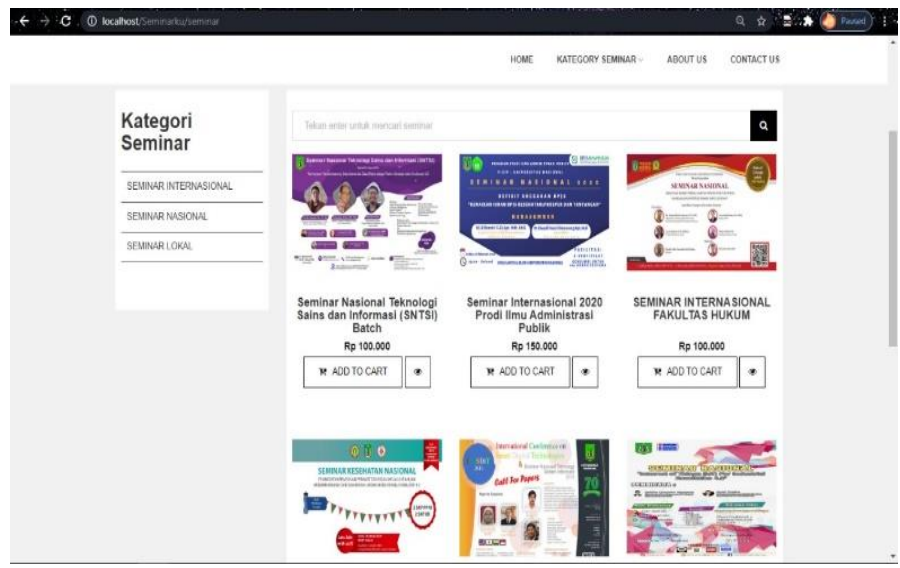

Gambar 5. Tampilan Daftar Seminar

\section{Halaman Login}

Setelah mengisi data pendaftaran, user sudah bisa masuk ke dalam fitur pemesanan tiket seminar. Tampilan dapat dilihat pada Gambar 6.

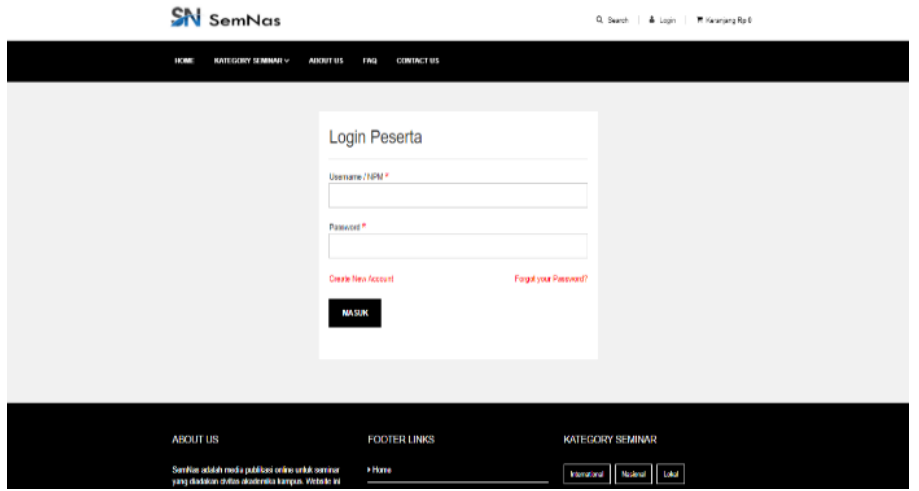

Gambar 6. Tampilan Login

\section{Halaman Registrasi}

Pada fitur ini, user di arahkan untuk daftar terlebih dahulu dengan mengisi Form regis untuk login dan dapatmenggunakan fitur yang ada di website. Tampilan dapat dilihat pada Gambar 7.

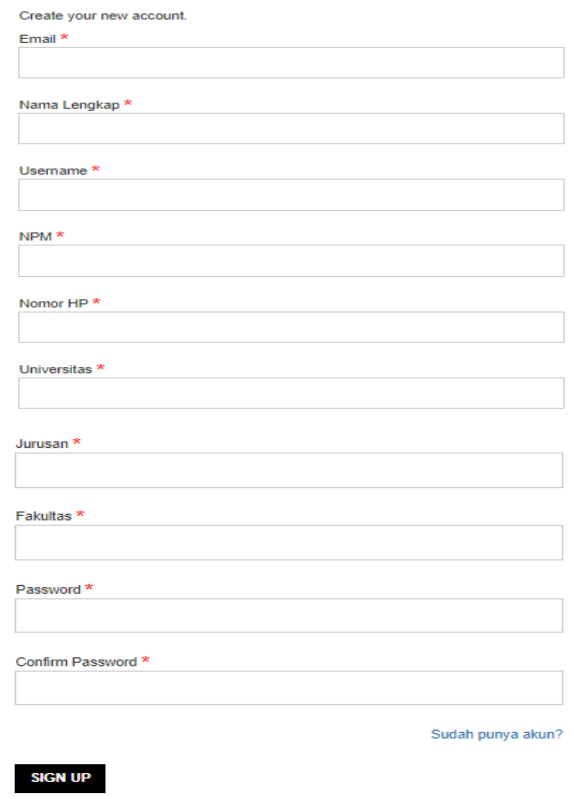

Gambar 7. Tampilan Registrasi 
JURNAL MEDIA INFORMATIKA BUDIDARMA

Volume 5, Nomor 1, Januari 2021, Page 216-223

ISSN 2614-5278 (media cetak), ISSN 2548-8368 (media online)

Available Online at https://ejurnal.stmik-budidarma.ac.id/index.php/mib DOI 10.30865/mib.v5i1.2642

\section{Halaman Profil}

Pada halaman profil, user dapat melihat dan mengedit nama, no hp informasi akun. Tampilan dapat dilihat pada Gambar 8 .

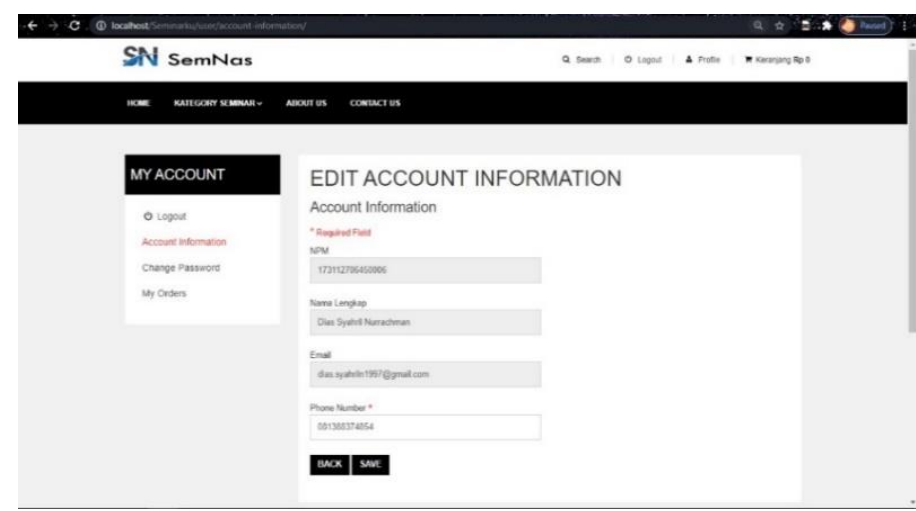

Gambar 8. Tampilan Profil

\section{Halaman CheckOut}

Halaman CheckOut adalah halaman pendataan seminar yang di ambil dan biaya yang harus di bayarkan untuk menyelesaikan pemesanan tiket seminar. Tampilan dapat dilihat pada Gambar 9.

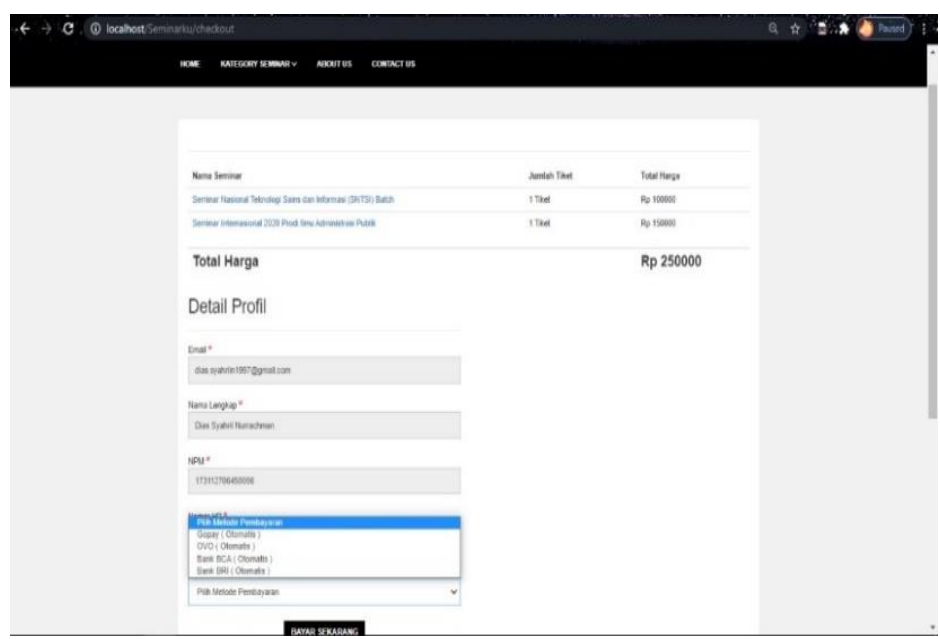

Gambar 9. Tampilan CheckOut

\section{Halaman Pembayaran}

Halaman ini terdapat status pembayaran user, jika sudah membayar maka status pembayaran menjadi "LUNAS", dan jika belum membayar maka status pembayaran "BELUM BAYAR". Tampilan dapat dilihat pada Gambar 10.
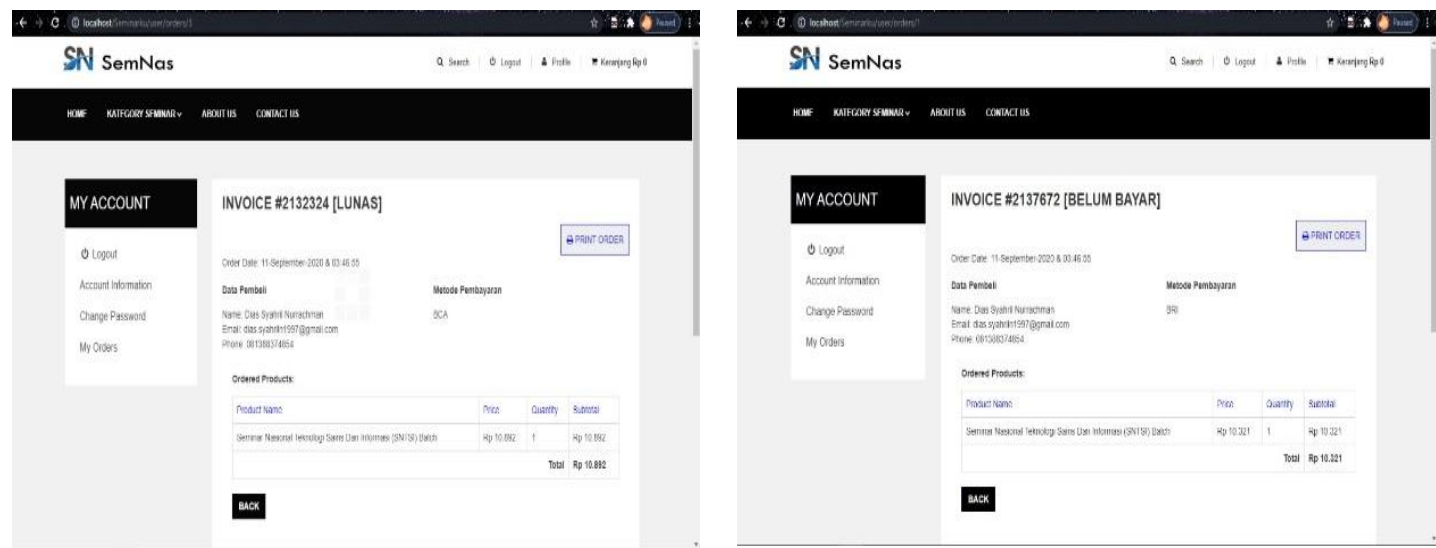

Gambar 10. Tampilan Status Pembayaran

\subsection{Pengujian Sistem}

Hasil Pengujian Unit beberapa halaman website, sebagai berikut : 
JURNAL MEDIA INFORMATIKA BUDIDARMA

Volume 5, Nomor 1, Januari 2021, Page 216-223

ISSN 2614-5278 (media cetak), ISSN 2548-8368 (media online)

Available Online at https://ejurnal.stmik-budidarma.ac.id/index.php/mib

DOI 10.30865/mib.v5i1.2642

Tabel 5. Tabel Pengujian Sistem

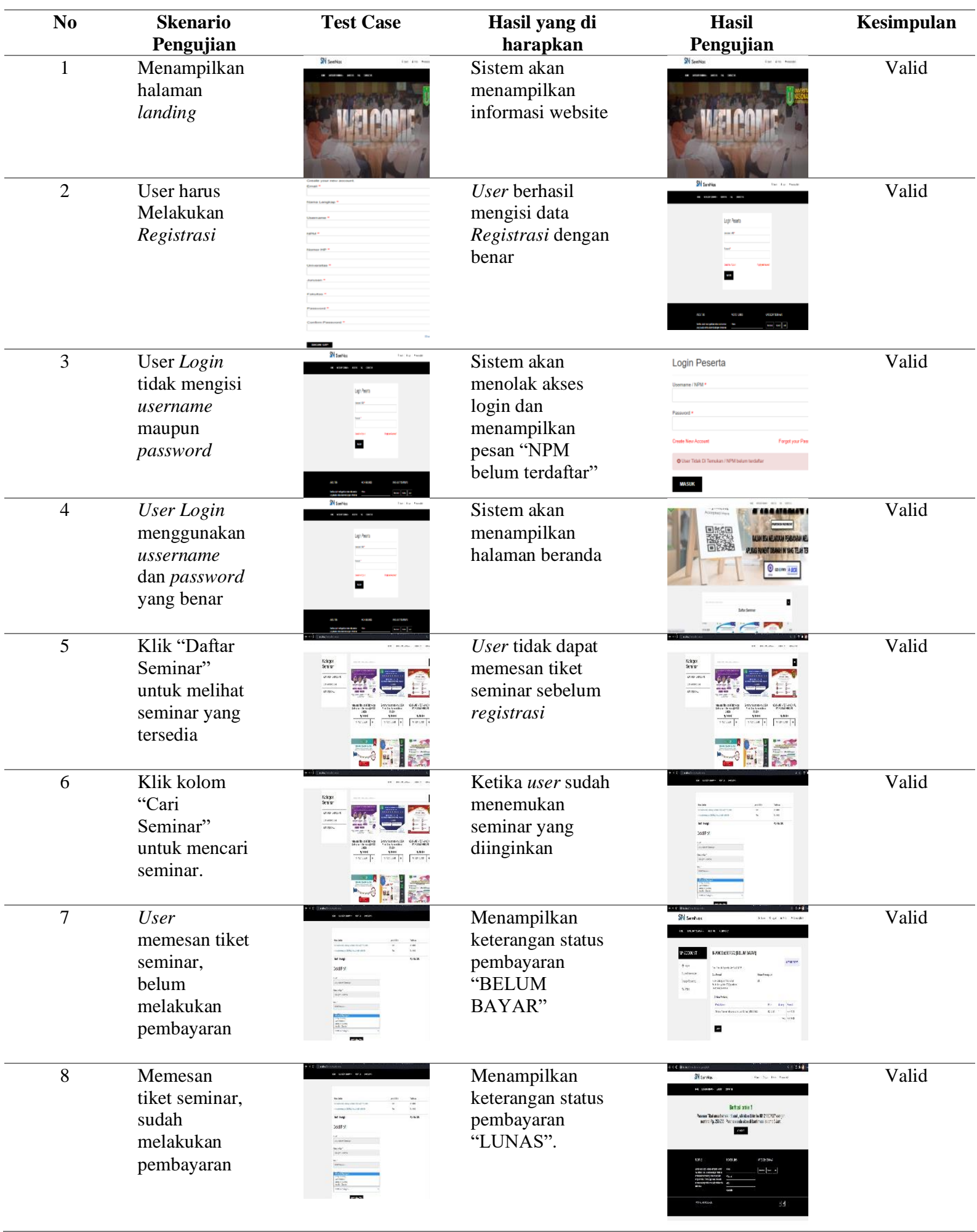

\section{KESIMPULAN}

Berdasarkan pada hasil penelitian yang telah dilakukan mengenai pemesanan tiket seminar secara online menggunakan Algoritma Apostolico, maka dapat diambil kesimpulan, dengan adanya website ini, khususnya mahasiswa Universitas Nasional dimudahkan untuk mendapatkan informasi maupun mendaftar seminar secara cepat. Aplikasi website ini juga memudahkan kinerja penyelenggara seminar dalam mendapatkan laporan/report secara detail. 
JURNAL MEDIA INFORMATIKA BUDIDARMA

Volume 5, Nomor 1, Januari 2021, Page 216-223

ISSN 2614-5278 (media cetak), ISSN 2548-8368 (media online)

Available Online at https://ejurnal.stmik-budidarma.ac.id/index.php/mib

DOI 10.30865/mib.v5i1.2642

\section{REFERENCES}

[1] Rizki Fajar Kurniasih, 2018. "Sistem Informasi Pendaftaran Peserta Symphosium Dan Workshop Berbasis Web", Universitas Dian Nuswantoro, 2018.

[2] Zen Munawar, "Aplikasi Registrasi Seminar Berbasis Web Menggunakan QR Code", TEMATIK - Jurnal Teknologi Informasi Dan Komunikasi Vol. 6, No.2 Desember 2019.

[3] Aldi Tri Bayu, "Rancang Bangun Aplikasi Pendaftaran Online Seminar Nasional”, Institut Bisnis dan Informatika Stikom Surabaya, 2018.

[4] Anisah, Sayuti, "Perancangan Sistem Informasi Registrasi Online Untuk Penerimaan Siswa Baru Berbasis Web", Jurnal SISFOKOM, Volume 07, Nomor 02, September 2018.

[5] Dewi Zahra, "Implementasi Algoritma Apostolico pada aplikasi kumpulan hadis shahih berbasis android" Fakultas llmu Komputer dan Teknologi Informasi Universitas Sumatera Utara, Medan, Skripsi, 2016.

[6] Eli Sapitri, Lince Tomoria, "Perancangan Aplikasi Chord Biola Lagu Pop Indonesia Dengan Menerapkan Algoritma Apostolico Crochemore Berbasis Android" Jurnal Majalah Ilmiah Informasi dan Teknologi Ilmiah (INTI) ISSN 23019425 (Media Cetak) Volume 7, No2, Februari 2020 Hal: 170-174

[7] Sindy Gita Ratri, "Penggunaan Algoritma Apostolico pada Proses Pencarian String di Dalam Teks", MAKALAH IF2251 STRATEGI ALGORITMIK TAHUN 2007.

[8] Yasir Nasution, "Aplikasi Pencarian File Berdasarkan Struktur Karakter Dengan Menggunakan Algoritma Apostolico Giancarlo", Universitas Sumatera Utara, Medan, 2016.

[9] Asroni, "Penerapan Model View Controller (MVC) Dengan Framework Codeigniter Pada Sistem Informasi Booking Wisata Klangon”, Jurnal BERDIKARI Vol.6 No.2 Agustus 2018.

[10] Kelvin dan Florensa Rosani Purba, "Analisis Dan Perancangan Website Pariwisata Dan Kebudayaan Pulau Bangka Berbasis PHP”, V5.3.1. Jurnal Teknik dan Ilmu Komputer, Vol.02 No. 07, 2013.

[11] Causa Prima Wijaya, Kodrat Iman Satoto, dan R. Rizal Isnanto, "Perancangan Sistem Informasi Pemesanan Tiket Travel Berbasis Web", Jurnal Transmisi 15, (2), 2013, 80, 2013.

[12] Irwin Nugroho, "Sistem Informasi Penerimaan Siswa Baru Berbasis Web Dengan PHP dan SQL", Universitas Negri Yogyakarata, Skripsi, 2011.

[13] Achmad Syafi Zain, dkk, "Pengembangan Sistem Informasi Penerimaan Siswa Baru Berbasis Web di SMA 1 Annuqayah Sumenep", Jurnal Ilmiah Edutic /Vol.4, No.2, 2018.

[14] Sugeng Priyanto, dkk, "Sistem Informasi Pendaftaran Mahasiswa Baru Berbasis Web Pada Politeknik Sains \& Teknologi Wiratama Maluku Utara", Indonesian Journal On Information system (IJIS)/ vol 3. No.1, 2018.

[15] Rusli Muhidin, N Faisal Kharie, Muin Kubais, "Analisis dan Perancangan Sistem Informasi Pada SMA Negeri 18 Halmahera Selatan Sebagai Media Promosi Berbasis Web”, IJIS- Indonesian Journal On Information System, Volume 2 Nomor 2, ISSN 2548-6438, 2017.

[16] Arisandy Ambarita, Sendiwati Haming, "Perancangan Sistem Informasi Administrasi Siswa Kursus Berbasis Web pada Lembaga Kursus dan Pelatihan Bina Ilmu Ternate", SAINTEK - Jurnal Sains dan Teknologi, Volume 5 Nomor, ISSN 2088-5911, 2014. 